\title{
GAMBARAN TEKANAN (STRESSORS) YANG DIHADAPI PASIEN SKIZOFRENIA RAWAT JALAN DAN STRATEGI COPING
}

\author{
Sakti Susilawati dan Muhammad Syafiq \\ Program Studi Psikologi Universitas Negeri Surabaya
}

\begin{abstract}
Abstrack : The aim of this study was to explore stressors faced by schizophrenic patients who have on-going treatments in Surabaya and to reveal strategies they employ to cope with the stressors. This was a qualitative research with a case study method. The participants of this study were two schizophrenic patients who have diagnosed by the expert as having paranoid and hebephrenic and schizophrenia have on going treatment. Data were collected through semi-structure interviews from main participants and their significant others and analyzed using thematic analysis. The results showed that the participants have experienced some stressors during on-going treatment process. Some of those stressors are: negative reaction from society, less attention from others, and loneliness. That stressors can become obstacles for schizophrenic patients to recover. To cope with the stressors, participants of this study employ two coping strategies, namely problem and emotion focused copings. The problem focused coping strategy helps participants to be directly active in solving the stressors. While, emotion focused coping strategy helps to control emotion and built their positive perspectives. In general, this study concludes that the participants use emotion focused coping when they are unable to solve stressors directly. Emotion focused coping helps participants to maintain their positive emotions. The participants' coping ability indicates that they have opportunity to decrease the possibility of relapse risk and engage in normal life.
\end{abstract}

Keywords: Schizophrenia, stressor, coping strategy

\begin{abstract}
Abstrak: Penelitian ini bertujuan untuk mengetahui gambaran stressor yang dialami oleh penderita skizofrenia rawat jalan atau sudah pada tahap remisi di Surabaya serta strategi yang digunakan untuk menghadapi stressor tersebut. Pendekatan kualitatif dengan metode studi kasus digunakan. Partisipan utama adalah tiga orang yang telah diagnosis oleh ahli sebagai penderita skizofrenia paranoid dan hebrefenik dalam tahap remisi. Data diperoleh melalui wawancara mendalam semiterstruktur dengan kedua partisipan dan significant others mereka. Data dianalisis menggunakan teknik analisis tematik. Hasil penelitian ini menunjukkan bahwa kedua partisipan mengalami beberapa stressor antara lain mendapatkan tanggapan negatif dari masyarakat, kurangnya perhatian dari orang terdekat, dan mengalami kesepian. Untuk menghadapi berbagai stressor tersebut, kedua partisipan menggunakan strategi berfokus pada masalah dan strategi berfokus pada emosi. Strategi coping berfokus pada masalah membantu partisipan untuk bertindak aktif secara langsung menyelesaikan masalah, sedangkan strategi coping berfokus pada emosi digunakan untuk membantu mengelolah emosi secara positif. Secara umum, penelitian ini menyimpulkan bahwa partisipan penelitian ini lebih sering menggunakan strategi coping yang berfokus pada emosi. Coping berfokus emosi membantu partisipan untuk mengatur dan mengendalikan emosi mereka. Kemampuan ketiga partisipan dalam melakukan coping terhadap berbagai stressor yang dialaminya menunjukkan peluang yang besar bagi mereka untuk mengurangi risiko kekambuhan dan hidup secara normal.
\end{abstract}

Kata kunci: Skizofrenia, Stressor, strategi coping

Korespondensi tentang artikel ini dapat dialamatkan kepada Sakti Susilawati melalui e-mail: sakti_s_ibrahim@yahoo.com 
Skizofrenia merupakan salah satu gangguan jiwa yang cukup banyak diderita oleh masyarakat Indonesia. Hasil Riset Kesehatan Dasar tahun 2007 oleh Badan Penelitian dan Pengembangan Kesehatan Departemen Kesehatan (2008) menunjukkan jumlah pasien gangguan jiwa berat atau skizofrenia adalah 0,46 persen dari populasi nasional. Jumlah penduduk Indonesia hasil sensus 2010 adalah 237.641.326 jiwa (Badan Pusat Statistik, 2010). Dengan demikian, diperkirakan sekitar 1,1 juta jiwa rakyat Indonesia saat ini menderita gangguan jiwa berat atau skizofrenia.

Skizofrenia didefinisikan sebagai penyakit pervasif yang mempengaruhi lingkup luas dari proses psikologis mencakup kognisi, afek dan perilaku (Arango, Kirkpatrick, \& Buchanan, 2000, dalam Nevid dkk. 2003:110). Sedangkan Depkes RI (1993), dalam PPDGJ, mendefinisikan skizofrenia sebagai gangguan jiwa yang ditandai oleh adanya distorsi dalam pikiran dan persepsi yang bersifat khas dan fundamental disertai dengan afek yang tumpul dan tidak wajar (Depkes RI, 1993). Orang yang mengalami skizofrenia mungkin berbicara monoton dan mempertahankan wajah tanpa ekspresi dan mungkin kehilangan kapasitas untuk mengekspresikan emosi mereka keluar (Nevid dkk, 2003). Penderita skizofrenia akan menunjukkan gejala-gejala seperti berperilaku aneh, mempertahankan aktivitas tertentu secara berulang-ulang seperti mondar-mandir, melamun, tidak mampu melakukan aktivitas mandiri seperti bekerja, mandi dan makan, pembicaraan dan persepsi yang tidak biasa, dan tidak jarang menujukkan perilaku agresif, seperti marahmarah atau menganggu orang sekitarnya (Davison dkk., 2006:444).

Terlepas dari semua karakteristik tersebut, halusinasi menjadi gangguan utama yang paling umum pada skizofrenia. Halusinasi adalah gambaran yang dipersepsikan tanpa adanya stimulus dari lingkungan (Nevid dkk, 2003). Orang yang mengalami skizofrenia mungkin dibanjiri informasi sensoris pada tingkat yang tinggi, namun memiliki kesulitan yang lebih besar dalam menyaring informasi yang berguna darinya. Akibatnya, mereka bingung dan merasa kesulitan untuk menyaring keluar stimulus yang tidak relevan seperti suarasuara yang mengganggu (Nevid dkk, 2003) . Mereka juga tidak dapat memandang perilaku mereka sebagai sesuai secara sosial atau tidak pada situasi tertentu karena mereka tidak dapat memandang segala sesuatu dari sudut pandang orang lain (Carini \& Nevid, 1992 dalam Nevid dkk. 2003:117). Karena itu, orang-orang dengan skizofrenia menunjukkan kemunduran yang jelas dalam fungsi sosial dan pekerjaan.

Namun skizofrenia bukanlah gangguan mental yang tidak dapat disembuhkan. Para penderita ini akan pulih setelah menjalani pengobatan dan terapi tertentu. New Freedom Commission untuk kesehatan mental dari Departemen Kesehatan Amerika Serikat (dalam Drake dkk., 2006) mendefinisikan orang yang telah pulih dari skizofrenia sebagai orang yang "hidup, belajar, bekerja, dan berpartisipasi penuh" dalam masyarakatnya meskipun ia harus terus-menerus menghadapi simptom skizofrenia (halusinasi atau delusi). Dalam penelitiannya terhadap 130 penderita skizofrenia yang sekaligus pecandu obat di New Hampshire, Amerika Serikat, Drake dkk. (2006) berhasil mengidentifikasi setidaknya 6 (enam) faktor penentu pemulihan (recovery), yaitu: mampu mengontrol simptom skizofrenia; berada dalam situasi kehidupan yang mandiri; bekerja secara kompetitif: memiliki kontak secara rutin dengan orang sekitar; menunjukkan level tertentu kepuasaan hidup: dan mampu menjauhkan diri dari obatobatan terlarang.

Mencapai proses pemulihan seperti yang dijelaskan tersebut, bukanlah hal yang mudah bagi beberapa penderita skizofrenia terutama bagi penderita skizofrenia remisi atau rawat jalan. Alasannya adalah menjalani remisi atau penyembuhan rawat jalan pada penderita skizofrenia tersebut adalah keadaan yang dapat mengundang banyak pemicu stress (stressors). Stressor adalah segala kejadian atau situasi yang menimbulkan perasaanperasaan tegang dan tertekan (Sarafino, dalam 
Smet, 1994: 108). Sebuah penelitian di Amerika yang dilaksanakan oleh Drake dkk. (2006) melaporkan beberapa stressor yang dialami oleh penderita skizofrenia rawat jalan, yaitu masih menghadapi delusi dan halusinasi, gejala depresi dan kecemasan, kesepian, kelelahan, dan perasaan malu. Semua tekanan tersebut menjadi faktor penyebab menurunnya fungsi sosial bagi pasien skizofrenia rawat jalan (Goldberg \& Schmidt, dalam Jetha, 2013).

Selain berbagai tekanan di atas, stigma atau tanggapan negatif juga rentan dialami oleh penderita skizofrenia rawat jalan. Hasil penelitiannya van Zelst (2009) menunjukkan bahwa stigmatisasi menjadi sebuah situasi interaksi negatif yang kronis dengan lingkungan yang harus dihadapi oleh pasien skizofrenia dalam kehidupan sehari-hari. Penelitian yang dilakukan oleh Yanos dkk. (2008) menunjukkan bahwa stigma yang terinternalisasi membawa dampak negatif terhadap harapan dan harga diri pasien hingga dapat menghambat penyembuhan. Penelitian tersebut merekomendasikan bahwa intervensi haruslah dibangun dan diuji untuk mengatasi dampak penting dari stigma yang terinternalisasi pada proses penyembuhan.

Penderita skizofrenia yang telah didiagnosis pulih dari gangguannya dan menjadi pasien rawat jalan memerlukan keterampilan menyelesaikan masalah dalam mengatasi stressor yang menekan tersebut agar dapat menjalani aktivitas kehidupannya secara normal. Kemampuan dalam mengatasi masalah ini umum disebut coping. Coping sering dimaknai sebagai apa yang dilakukan oleh individu untuk menguasai situasi yang dinilai sebagai suatu tantangan, luka, kehilangan, dan ancaman (Siswanto, 2007:60). Lazarus \& Folkman (dalam Smet, 1994:143), menggambarkan coping adalah proses ketika individu mencoba untuk mengelola dan mengatur jarak antara keinginan dari dalam diri individu dan tuntutan lingkungan. Individu akan menggunakan sumber daya mereka dalam menghadapi situasi.

Strategi coping yang tepat dapat membantu penderita skizofrenia untuk mengurangi resiko kekambuhan. Strategi coping secara umum dibedakan dalam dua fungsi, yaitu problem focused coping dan emotion focused coping. Problem focused coping adalah usaha dari individu yang secara aktif mencari penyelesaian dari masalah untuk menghilangkan kondisi atau situasi yang menimbulkan stress. Individu juga akan mengurangi dan mengatasi stressor dengan mempelajari cara-cara baru. Strategi ini biasanya akan digunakan oleh individu ketika dirinya yakin dapat menguasai dan mengubah stressor. Stressor akan hilang jika individu mampu mengatasinya dengan menggunakan coping yang efektif (Ridner, dalam Drapeau 2006 ).

Berdasarkan latar belakang masalah tersebut, penelitian ini bertujuan untuk mengungkap tekanan-tekanan (stressors) yang dialami pasien skizofrenia rawat jalan (remisi) di Surabaya; bagaimana tekanantekanan tersebut mempengaruhi kehidupan personal dan sosial mereka; dan strategi apa saja yang digunakan mereka dalam upaya untuk mengatasi berbagai tekanan tersebut.

\section{METODE}

Penelitian ini menggunakan pendekatan kualitatif dengan metode studi kasus. Studi kasus adalah penelitian kualitatif yang berupaya menemukan makna, menyelidiki proses, dan memperoleh pengertian dan pemahaman yang mendalam dari individu, kelompok, atau situasi (Emzir, 2010:20). Kasus yang diangkat dalam penelitian ini adalah tekanan dan strategi coping penderita skizofrenia yang rawat jalan. Studi kasus dalam penelitian ini menggunakan tipe studi kasus instrinsik. Penelitian ini bertujuan untuk memahami secara utuh suatu kasus yang akan di teliti dan tidak ada maksud untuk membangun suatu teori baru atau menghasilkan suatu rekomendasi kebijakan (Yin, 2000) .

\section{Partisipan}

Penelitian ini 3 (tiga) partisipan. Partisipan pertama (P1) seorang laki-laki 
berinisial PG yang berusia 44 tahun dengan gejala skizofrenia paranoid didapatkan atas bantuan dari pihak Rumah Sakit Jiwa, sedangkan partisipan kedua (P2) berjenis kelamin perempuan dengan inisial AS berusia 37 tahun dan didiagnosis skizofrenia hebefrenik oleh seorang psikiater. Partisipan ketiga (P3) adalah seorang perempuan berinisial RT berusia 45 tahun yang direkrut peneliti dari Komunitas Skizofrenia Surabaya.

Teknik perekrutan partisipan yang digunakan dalam penelitian ini adalah pemilihan secara pusposive sampling. Dalam teknik ini, peneliti menetapkan kriteriakriteria partisipan terlebih dahulu kemudian memilih partisipan berdasarkan kriteria tersebut. Adapun kriteria partisipan dalam penelitian ini adalah : (1) Partisipan adalah Pasien Skizofrenia yang masih menjalani pengobatan rawat jalan; (2) Pasien didiagnosa Skizofrenia oleh ahli (Psikolog/Psikiater); (4) Telah diizinkan oleh pihak Rumah Sakit / Psikiater dan partisipan bersedia untuk diminta informasi.

\section{Teknik Pengumpulan Data}

Penelitian ini menggunakan alat pengumpulan data berupa wawancara, dan dokumen. Wawancara yang dilakukan adalah wawancara mendalam (depth interview) untuk menggali data dalam penelitian tersebut. Wawancara dilakukan untuk memperoleh pengetahuan tentang makna-makna subjektif yang dipahami individu berkenaan dengan topik yang diteliti dan bermaksud melakukan eksplorasi terhadap isu-isu lain yang berkaitan dengan topik tersebut (Poerwandari, 2001). Penelitian ini menggunakan jenis wawancara semi terstruktur dengan petunjuk umum. Jenis wawancara ini mengharuskan pewawancara membuat kerangka dan garis besar pokokpokok yang dirumuskan tidak perlu ditanyakan secara berurutan. Demikian pula penggunaan dan pemilihan kata-kata untuk wawancara dalam hal tertentu dilakukan sebelumnya (Patton, dalam Moleong, 2010). Pendekatan dengan partisipan dilakukan membangun rapport terlebih dahulu. Proses wawancara masing-masing dilakukan berkisar 60 menit dalam dua kali pertemuan

\section{Teknik Analisis Data}

Analisis data yang digunakan dalam penelitian ini adalah analisis tematik. Analisis tematik adalah metode untuk mengidentifikasi, menganalisa, dan melaporkan pola-pola (tema) dalam data (Braun \& Clarke, 2006). Langkah pertama yang dilakukan oleh peneliti adalah mentranskrip data hasil wawancara berupa verbatim. Langkah berikutnya melakukan coding, diberikan untuk menentukan subtema dan tema besar. Kemudian coding yang memiliki keterikatan yang sama dikelompokkan menjadi satu dalam sub-tema yang mewakili makna keseluruhan dari coding. Setelah sub-tema didapatkan, maka langkah berikutnya adalah menggolongkan sub-tema yang memiliki kesamaan yang terikat pada satu tema besar. Langkah akhir, peneliti melakukan analisis dan penulisan laporan penelitian.

Kredibilitas penelitian ini berupaya dicapai dengan menggunakan triangulasi sumber data, yaitu menggali data dari significant others kedua partisipan utama. Cara lainnya adalah dengan melibatkan peneliti kedua untuk mengurangi subjektifitas dan menjaga transparansi. Dalam menjaga interpretasi agar tidak menyimpang, teknik grounding in examples yang dianjurkan oleh Elliot dkk. (1999) juga digunakan. Dalam teknik ini, peneliti mengutip ekstrak transkrip wawancara untuk memperkuat argumen atau interpretasi. Lambang dalam kurung persegi berisi tiga titik, '[...]', digunakan dalam kutipan ekstrak untuk menunjukkan bahwa ada materi yang dihapus karena tidak relevan. Sedangkan kata atau kalimat dalam tanda kurung biasa, '( )', merupakan tambahan dari penulis untuk mengklarifikasi maksud atau makna dari ekstrak.

\section{HASIL}

Penelitian ini berhasil mengungkapkan 2 (dua) tema besar, tema yang pertama yaitu tekanan yang dialami akibat skizofrenia, dengan sub-tema mengalami halusinasi; tanggapan negatif; efek negatif obat; kurangnya perhatian dari 
orang terdekat; mudah stres karena masalah ringan; skizofrenia membuat mudah lelah; mengalami kesepian; dan takut dijauhi karena mengalami skizofrenia. Kemudian, tema terakhir yaitu strategi coping untuk mengatasi masalah yang terdiri atas 2 (dua) sub-tema, penyelesaian berfokus pada masalah (problem focused coping) dan penyelesaian berfokus pada emosi (emotion focused Coping). Strategi coping yang berfokus pada emosimeliputi beberapa topik antara lain mengalihkan tekanan ke aktivitas lain; menyelesaikan tanggapan negatif; menahan dan mengekspresikan emosi; mencari dukungan moral; mengubah pandangan tentang tekanan dan menerima kondisi.

\section{Tema : Tekanan yang dialami akibat skizofrenia}

\section{Mendapatkan tanggapan negatif}

Kembalinya mantan penderita skizofrenia secara penuh pada perilaku yang normal bukanlah suatu hal yang mudah. Sebagian masyarakat awam tidak memahami skizofrenia. Orang dengan skizofrenia juga seringkali dianggap tidak dapat sembuh. Karena itu, ketika penderita sudah remisi dan kembali ke keluarga dan masyarakatnya, seringkali mendapat tanggapan negatif. Tanggapan negatif yang dialaminya yaitu berupa julukan gendeng (gila).

"[...] Seperti orang sakit jiwa, orang normal aja di olok "koen gendeng" (kamu gila), ya siapa sih yang mau.Ya ada penolakan pasti ada [...] ." (P1-B259).

Partisipan 1 menceritakan ketika berkumpul dengan teman-temannya, status partisipan yang pernah dirawat dan saat ini menjalani pengobatan rawat jalan sebagai penderita skizofrenia menjadi bahan canda. Julukan gendeng kepada dirinya menjadi bahan tertawaan ketika berkumpul bersama teman-temannya. Partisipan memberikan persamaan bahwa orang normal saja apabila diberikan olokan gendeng saja tidak menerima begitu juga dengan dirinya. Partisipan juga menyadari penolakan yang dialaminya namun hal tersebut tidak terlalu berpengaruh untuk dirinya.

"Iya. jadi aku kayaknya pernah merasa sakit hati juga dibilang gendeng,,"oh iya areke rodo gendeng", aku kan dengar dari belakang dia ngomong sama orang kayak gitu [...]." (P2 -B349).

Sama halnya dengan partisipan 1, partisipan 2 juga menerima tanggapan negatif seperti julukan gendeng. Ketika kondisi dimana partisipan 2 berperilaku aneh, hanya keluarga yang mengetahui. Partisipan 2 menceritakan pernah mendapat tanggapan negatif berupa julukan gendeng oleh saudaranya. Ketika dia akan berobat kepada orang pintar. Saudaranya lalu mengatakan kepada orang pintar tersebut bahwa partisipan itu gendeng. Mendengar tanggapan tersebut, partisipan sakit hati namun dia memilih untuk diam.

\section{Kurangnya perhatian dari orang terdekat.}

Peran orang terdekat untuk membantu salah satu keluarganya yang mengalami skizofrenia sangat penting sekali. Karena semua berawal dari hubungan keluarga. Keluarga yang tidak peduli dan tidak memperhatikan dikhawatirkan akan memberikan dampak kekambuhan kepada penderita skizofrenia. Padahal, perhatian yang diberikan dapat memberikan motivasi kepada penderita skizofrenia dan membuat dirinya merasa masih dibutuhkan dengan kasih sayang dari orang terdekatnya.

Seperti yang dialami oleh partisipan 2, melaporkan bawah dirinya merasa kurang diperhatikan oleh keluarganya.

"Beberapa tahun yang awal-awal keluarga masih dukung aku kan, maksudnya sabar dengan aku trus mungkin sekarang mereka sudah mulai capek trus atau mungkin aku gregetan (kesal) atau gak mau, jadi sempat itu gak bantu aku jadi misalkan aku sakit bapakku gak bisa ngantar, mungkin karena dia (sudah) tua, [...]." (P2- B225). 
Awal-awal mengalami gangguan skizofrenia, partisipan mendapatkan perhatian penuh oleh keluarga khususnya Ayah. Saat ini partisipan tinggal bersama Ayah, adik dan Ibu tirinya. Namun, partisipan menyadari bahwa tidak selamanya mungkin keluarga akan terus-terus memperhatikannya. Partisipan mengerti dengan kondisi-kondisi yang dialami oleh keluarga. Ada kala waktu keluarga membantu dan tidak. Ayah partisipan sudah tua, mungkin faktor usia karena sudah tua maka hingga saat ini jarang menemani partisipan untuk berobat dan adiknya tidak mengantarnya bepergian. Sedangkan, pada partisipan 3 merasa suaminya kurang memperhatikan.

"Kadang kalau terlalu sakit saya nangis. Kalau nangis gitu suami saya kan gak seperti pria lain kan yang romantis gitu loh, kalau nangis ditanyain kenapakenapa gitu kan. Kalau suami saya endak , biarin ya nangis." (P3-B668).

Partisipan merasakan kurang perhatian dari suaminya. Suaminya yang cuek apabila partisipan menangis. Dengan begitu, partisipan menyelesaikan semua permasalahannya sendiri. Partisipan merasa lelah, namun dia beranggapan bahwa hidup itu tidak boleh lelah. Partisipan ingin berbagi masalah yang dihadapinya, ingin ada yang melindungi dan memperhatikan dia. Dengan status sebagai skizofrenia dirinya ingin ada seseorang yang memperhatikannya dia kasih dan sayang namun suaminya tidak memberikan perhatian.

\section{Merasa mudah lelah}

Penderita skizofrenia akan mengalami penurunan efektivitas fisiknya. Kemunduran fungsi fisik seperti mudah lelah apabila banyak melakukan kegiatan dan tidak dapat berkonsentrasi penuh dalam beberapa hal. Partisipan 2 akan mengalami kelelahan apabila harus mengerjakan banyak pekerjaan.

"misalkan kalau orang normal ia punya tenaga kua.t Dia sehari sekali atau apa aku mungkin dua hari sekali atau 3 hari sekali baru bisa nyapu-nyapu kayak gitu. Jadi gak bisa terlalu dipres (dipaksa) teraturan begitu kayak gitu, aku kalau misalkan dipaksa kayak gitu misalkan aku harus nyapu yang sreg kayak gitu nanti akhirnya aku jadi sakit." (P2 -B314).

Partisipan mengeluhkan pekerjaan rumah yang harus dia selesaikan. Dia bercerita bahwa dirinya akan mudah sakit apabila banyak kegiatan melelahkan yang harus dia kerjakan. Dia membandingkan dirinya dengan orang yang normal mampu mengerjakan pekerjaan rumah dengan teratur sedangkan dirinya apabila terlalu dipaksakan akan membuat dirinya jatuh sakit. Sedangkan, partisipan 3 mengeluhkan tentang sulitnya konsentrasi.

\section{"Dulu suka tapi kalau sekarang endak, mungkin gak konsen (konsentrasi). Kalau dulu saya senang baca apa saja, senang saya gitu mulai kecil yang Sarinah (judul buku) gitu, Bung karno (buku sejarah), ya tebal-tebal. Sejak kecil senang saya, tapi sekarang semenjak kena skizo ( skizofrenia) gak minat sama sekali. Saya sudah berusaha maksimal ke perpus (perpustakaan) itu jadi saya cuma lihat gambar-gambarnya aja. Saya sudah fokuskan baca tapi kalah (tidak mampu) [...].” (P3 -B75).}

Sebelum menderita skizofrenia, partisipan 3 sangat senang membaca buku. Namun, semenjak terkena skiozfrenia, partisipan tidak minat lagi membaca. Dirinya sudah berusaha untuk membaca namun tidak mudah konsentrasi. Partisipan tetap melakukan aktivitas ke perpustakaan walau hanya sekedar melihat gambar-gambarnya saja.

\section{Mengalami kesepian}

Partisipan melaporkan bahwa dirinya mudah merasa kesepian. Rasa kesepian ini disebabkan oleh kegiatan yang monoton. Selain itu, kesepian karena kesendirian, membutuhkan seseorang yang dapat mengisi keseharian. Serta, seorang teman untuk diajak bertukar pikiran atau mengobrol dan memberikan dukungan atau masukan saran. 
Individu akan merasa kesepiannya hilang ketika bersama dengan situasi dan seseorang yang menyenangkan membuat dirinya aman dan nyaman walau dalam kondisi tertekan sekaligus.

"[...] aku bilang kok hari-hari ini gampang banget lonely (kesepian) gitu kan ya, kok lain sama dulu aku tuh, kalau dulu mungkin passion (semangat) ku karena belajar, kerja, kuliah dan aku mendapatkan kepuasan di situ karena itu keinginanku kali ya. Sekarang aku selama ini kerja, kerja juga tapi dapatnya ya ginigini aja, ya maksudnya kayaknya kepingin, ya kerja tuh harus ya memang harus untuk menghidupkan aku sendiri kan, trus habis itu jadi itu kepingin cari jodoh [...]." (P2-B58).

Partisipan 2 membandingkan dirinya yang dulu dengan yang sekarang. Dahulu partisipan kesehariannya diisi dengan kegiatan seperti kuliah dan kerja. Kesehariannya juga dilakukan dengan kegiatan belajar. Partisipan mengeluhkan keadaannya mengenai pekerjaan yang penghasilannya terkadang tidak memuaskan. Namun, partisipan menyadari tuntutan ekonomi mengharuskan dia tetap bekerja. Kesepian karena belum mempunyai pasangan juga menjadi faktor kejenuhan yang dirasakan dan dirinya berniat untuk mencari jodoh. Sedangkan, pada partisipan 2 selalu menangani masalahnya sendiri, namun dirinya merasakan jenuh karena kesepian.

"[...] Loh memang, saya bisa ngatasi ya memang, tapi sekali waktu loh, kadang jenuh gitu loh mba, saya kepengen cari teman yang bisa di ajak-ajak ngobrol enak gitu ya, tukar pendapat gimana enaknya, trus sharing-sharing apa gimana[...]." (P2--B723).

Partisipan membutuhkan seorang teman untuk saling berbagi cerita. Selain jenuh karena tidak mempunyai teman untuk saling berbagi cerita, partisipan juga belum merasakaan kehadiran seorang anak didalam kehidupan rumah tangganya, kemudian partisipan ditawari untuk mengadopsi seorang anak dari temannya. Lalu, partisipan ada niatan untuk mengadopsi anak, namun keinginan tersebut diurungkan niatnya karena suaminya tidak setuju.

\section{Tema : Strategi Coping untuk mengatasi tekanan}

Coping ialah cara individu untuk mengatasi dan mengurangi tekanan. Ada dua cara yang ditempuh partisipan untuk menyelesaikan masalahnya yaitu penyelesaian berfokus pada masalah (problem focused coping) dan penyelesaian berfokus pada emosi (emotion focused coping). Problem focused coping sebagai usaha dari individu yang secara aktif mencari penyelesaian dari masalah untuk menghilangkan kondisi atau situasi yang menimbulkan stres (Folkman \& Lazarus, 1984:46).

Hasil penelitian ini menunjukkan para partisipan cenderung menggunakan kedua jenis strategi tersebut. Namun, strategi penanggulangan masalah yang berfokus pada emosi tampak lebih dominan.

\section{Penyelesaian berfokus pada masalah}

Upaya-upaya lain yang dilakukan antara lain mengambil langkah aktif seperti mempersiapkan rencana untuk menyelesaikan dan menjauhkan diri dari stressor. Seperti stressor efek negatif obat yang dialami oleh kedua partisipan.

"Dikasih buku ini sama teman orang ini, dikasih buku apa, Andri Gunawan. Ini institute of mind technology, ini motivator no.1 di se Indonesia yg paling dicari, niatnya kesana, ini kan terapi saya coba katanya gak bisa, [...].” (P1-B349).

Partisipan 1 juga aktif mencari informasi dengan cara mendatangi tempat terapi berupa hipnoterapi.

"[...] obat merasa ngantuk atau melayang itu, ngantuk jadi ya aku kurangi, tapi katanya ga apa sehari 2 kali, [...] tapi ya untuk mengatasinya aku tetap konseling ya minum obat. Kalau boleh dikurangi sama dokternya ya gak apa." (P2-B165). 
Partisipan 2 aktif melakukan usaha dengan cara mengurangi obatnya menjadi dua hari sekali. Selain obat, partisipan 2 juga tetap melakukan.

Kedua partisipan juga mencari informasi dan bantuan. Informasi dan bantuan ini juga termasuk dukungan sosial.

“[...] cerita ke Ibu, kadang kalau saya frontal seperti marah-marah ya ibu diam. Kadang ya saya nyadar. Ibu bilang "kamu urus sendiri saja". Saya kan pernah minta bantuan sama RT (Rukun Tetangga), tetangga dekat. Saya minta bantuin buat surat tapi dia malah merespon gak menyenangkan. Harusnya kan dia bilang dengan kata-kata bijak. Harusnya kayak gini bilang, "kamu kan sakit, jadi harus begini" tapi saya biarin aja." (P1-B69).

Sejak kecil Partisipan 1 adalah anak yatim, orang yang paling dekat dengan dirinya hanya sang Ibu. Ketika partisipan mendapatkan masalah, dirinya akan menceritakan ke ibunya. Sang ibu memberikan solusi informasi tapi terkadang juga ibunya hanya menyuruh Partisipan untuk menyelesaikannya sendiri.

Partisipan 2 menggunakan upaya mencari bantuan secara langsung agar mendapatkan bantuan yang membantunya menyelesaikan masalah. Dirinya kesulitan dana lalu mendapatkan dana pinjaman dari kakaknya, sehingga bebannya mulai berkurang.
"Alhamdulillah, kadang kalau ada masalah aku kan mikir sendiri jalan keluarku gini, dari pikiran ku gini aku cerita ke psikiaternya ternyata jalan pikiran aku sama dia sama, benar gitu. Aku cerita ke mbaku ya ada solusinya jadi kadang masih dikasih (uang) [...].” (P2- B510).

\section{Penyelesaian berfokus pada emosi}

Strategi penanggulangan yang berfokus pada emosi, yaitu bertujuan mengontrol respon emosional, untuk membantunya agar mengatur emosi yang diinginkan dari stressor yang muncul, serta menerima dan berfikir positif.

\section{Mengalihkan stressor ke aktivitas lain}

Untuk melepaskan stressor dari suarasuara tersebut, partisipan melakukan pengalihan dengan melakukan aktivitas lainnya.

"Ada halusinasi saya hilangkan, ya saya mencari keinginan untuk menyenangkan keinginan (aktivitas bermain musik)." (P1-B16).

Kegiatan yang dilakukan oleh partisipan yaitu menghibur diri dengan bermain gitar.

"Dulu ada suara-suara jelas banget sekarang udah gak, mungkin karena obat jadi gak usah di reken." (P2- B462)

Berbeda dengan partisipan 1, partisipan 2 akan mengabaikan suara-suara yang tidak jelas. Partisipan 2, menceritakan bahwa dirinya merasa mendengar suara jin dan suara orang tertawa, bahkan suara yang memerintahkannya untuk membunuh.

Mengalihkan stressor dengan melakukan aktivitas lain dilakukan oleh partisipan dengan bekerja. Bekerja dalam hal ini, sebagai harga diri yang harus dimiliki agar dihargai oleh orang lain. Harga diri sebagai penilaian diri yang dipengaruhi oleh sikap, interaksi, penghargaan, dan penerimaan lain terhadap individu.

\footnotetext{
"Sekarang udah gak pernah, karena saya bekerja jadi saya dihargai. Dulu sebelum kerja saya di ketawain orang. Saya dianggap lucu karenasaya diam dan kaki saya tidak bergerak-gerak, saya diam di depan rumah. Mungkin karena lucu saya keluar masuk rumah.” (P1- B38).
}

Sebelum dirinya bekerja, hanya beberapa orang saja yang mengajaknya bicara. Partisipan merasa pekerjaan adalah harga diri baginya.

Partisipan 2 beranggapan agar dihargai oleh orang lain maka harus berharga. Berharga yang dimaksud adalah berkerja mencari uang. 
"ya berarti aku misalkan harus dihargai orang aku harus berharga juga misalkan aku harus nyari duitkayak gitu itu jadi kan orang gak akan olok aku kan, orang normal aja gelandangan diolokin orang kayak gitu kan. Kalau pengen dihargai dia harus jadi orang berharga.” (P2-B364).

Bekerja juga dapat membantunya agar tidak mendapatkan olokan. Hal yang sama juga terjadi pada partisipan 3 :

"Malah saya dianggap bukan orang penyakitan. Dianggap seperti biasa. Malah kalau di rumah itu saya dianggap punya kemampuan untuk mencari uang yang lebih baik. Jadi kalau saya tuh, disuruh untuk membantu keluarga saya gitu." (P3 -B222).

Partisipan 3 merupakan sosok yang aktif bekerja. Dirinya dianggap mampu mencari uang yang lebih baik dibanding dengan saudaranya yang lain. Karena kemampuan dan mempunya uang yang cukup, partisipan seringkali membantu keluarganya apabila ada kesulitan dana keuangan.

\section{Mengabaikan tanggapan negatif}

Dalam menanggapi pandangan negative seperti julukan "gendeng" partisipan 1 memilih mengabaikan.

"Saya cuekin aja, kalau ngikutin omongan orang terus gak selesai-selesai." (P1-B66).

“.. tapi ya wes gak apa sama teman juga, orang sakit jiwa dari dulu julukannya gendeng ya wes, ya sudah.” (P1-B263).

Menurutnya, apabila mengikuti omongan orang lain yang menanggapinya negatif tidak akan selesai. Partisipan 3 juga mendapatkan tanggapan negatif dari temantemannya namun dirinya mengabaikan hal tersebut.

"Iki biyen tahu stres iki, uwong stres (orang ini pernah stres, orang stres),",wes biarin saya cuekiin tok (ya sudah saya biarkan saja)." (P3- B171).
"Iya biasa, gak saya hiraukan. Kalau biasa ya biasa. Teman saya kan biasa ya olokan gitu "iki kakean obat" (orang ini kebanyakan obat) gitu kan. Jadi kalau ketawa gitu jadi saya anggap biasa." (P3B214)

Partisipan tidak menghiraukan tanggapan temannya yang mengolok-olok dirinya orang stres dan kebanyakan obat. Dirinya tidak mempermasalahkan dan menganggap itu hal yang biasa.

"Enggak ada saya, ya kalau aku sih cuek aja, lakuin yang terbaik buat kita, cuek kata orang. Gak ngurus gitu loh, saya butuh ini orang bilang apa terserah pokoknya gak tersakiti gitu." (P3- B356)

Partisipan memilih cuek apabila ada yang memberikan tanggapan negatif kepada dirinya selama itu tidak menyakitinya. Pengabaian merupakan coping untuk mengatasi emosi negatif seperti meredakan emosi individu yang ditimbulkan oleh stressor tanpa berusaha mengubah situasi yang menjadi sumber tekanan. Usaha coping ini yang disadari untuk tidak memikirkan masalah dan bersikap seolah-olah tidak ada sesuatu yang terjadi.

\section{Mencari dukungan sosial}

Dukungan sosial diperoleh para partisipan dengan mendengarkan pandangan positif teman-temannya. Dukungan sosial dapat berbentuk perhatian, pemberian informasi, atau saran yang memotivasi. Partisipan 1 dan 2 melaporkan bahwa ia memiliki teman yang memandangnya positif.

"Saya menunjukkan saya sebagai orang sakit jiwa. Ada suatu omongan teman, 'gak usah begitu kamu sehat kok, ndak sakit'. Tapi, karena saya masih minum obat jadi saya menyimpulkan saya masih sakit.” (P1 -B31).

"Aku kalau cerita sama yang tahu tentang skizofrenia, ada temanku juga, teman kos, (bilang): "mbak sebenarnya gak sakit cuma kondisi aja, orang kalau kencing 
manis harus minum obat, sama kayak mbak." (P2- B76).

Partisipan mendapat motivasi dari temannya bahwa ia tidak sakit. Kondisi saat ini yang mengharuskan mereka berdua minum obat tidak tidak dipandang sebagai tanda bahwa mereka sakit. Kedua partisipan merasa terbantu dengan pandangan positif dari teman-temannya tersebut.

Partispan 3 memperoleh dukungan sosial dengan bergabung dengan komunitas online peduli skizofrenia. Ia mendapat kekuatan dengan berbagi cerita tentang masalah yang ia hadapi kepada teman di komunuitas tersebut.

"Saya baca-baca di KPS (Komunitas Peduli Skizofrenia Indonesia) saja sudah cukup kalau kadang saya mikirnya bukan penyakit keluhan saya itu. [...] Ya tetap pikiran saya seperti orang waras biasa."(P3- B482).

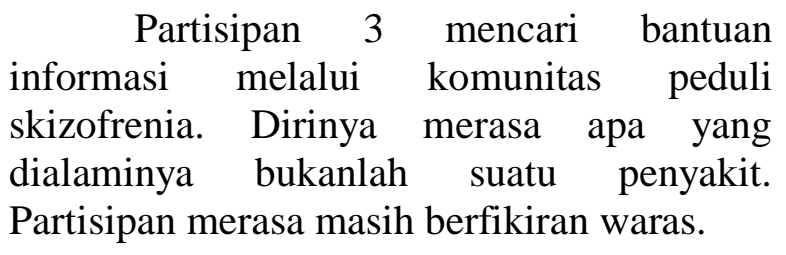

\section{Mengambil pandangan positif}

Semua usaha yang ketiga partisipan lakukan terkadang tidak menyenangkan untuk dilakukan, namun apabila tidak dilakukan juga akan mendapatkan dampak yang bisa saja menjadi lebih buruk. Ketiga partisipan kemudian mencoba melakukan strategi kognitif untuk menilai kembali atau mengubah pandangan mengenai situasi tekanan.

"aku kan dulu juga pernah kayak gitu juga pengen bunuh diri, trus habis gitu sakit kayak gini udahlah dikasih nasehat akhirnya hilang gitu loh persepsi keinginan untuk bunuh diri, Alhamdulillah aku dikasih hidup ya Allah, berusaha mencari positif tentang pandangan hidup gitu loh."[...],. (P2B211).

Partisipan 2 pernah ada niatan untuk bunuh diri, namun karena diberikan nasehat dan mengubah persepsinya dengan keadaan yang ia alami membuat dia bersyukur dengan situasi ini dan berusaha mencari hal positif lainnya.

"Alhamdulillah aku dikasih hidup ya Allah, berusaha mencari positif tentang pandangan hidup gitu loh.”(P2-B13).

Partisipan mencoba mengubah pandangannya pada keadaan yang di alami dengan cara pandang yang positif dan syukur.

Menerima keadaan yang dialaminya membuat partisipan belajar untuk menafsirkan keadaan ini secara positif. Seperti yang dilakukan oleh partisipan 2 dan partisipan 3.

"Mulai menginjak tahun ke 12
pernikahan, sekarang melangkah tahun ke
17 saya sudah sepakat saya gak mikirin
anak lagi, saya harus memikirkan masa
depan saya, soalnya kalau saya mikir ke
anak terus kemungkinan saya kena
skizfofrenia terus. (P3-B634)

Menjalani pernikahan menginjak usia ke 17 tahun namun belum juga mendapatkan seorang anak, partisipan sudah memutuskan untuk tidak lagi memikirkan persoalan anak. Partisipan memilih untuk memikirkan masa depannya. Apabila dirinya terus-terus memikirkan hal tersebut dikhawatirkan akan kambuh lagi skiozfrenianya, karena tekanan yang dialaminya dipikirkan begitu dalam hingga tegang.

Partisipan menyadari kebutuhan memperoleh anak, keluarga juga menginginkan hal tersebut. Apabila hal ini terus-terus dipermasalahkan maka tidak akan terselesaikan karena memang kondisi saat ini dirinya belum dapat mempunyai anak.

\section{Menerima kondisi}

Melewati situasi yang menekan membuat partisipan belajar hidup dengan kekurangannya. Partisipan mencoba menerima dengan tabah mengenai kondisi yang dialaminya.

"Sekarang pertama aku nerima aja, dulu aku punya target gini-gini sekarang aku 
mengalami keterpurukan putus asa aku ngalami gitu dulu semangatku banyak berapa persen gitu sekarang gak seberapa ini juga gak muluk-muluk dulu cita-cita aku ada target sekarang ya udahlah nerima aja udah usaha ya nerima aja ya mungkin fasenya gitu ada orang yang semangat gak putus asa jadi ya ku ngalami sekarang ya tetap semangat usaha tapi gak kayak dulu..” (P2-B529)

Partisipan 2 menerima keadaannya saat ini. Ia membandingkan dirinya yang dulu sebelum didiagnosis skizofrenia dan sekarang berbeda. Ia pmelaporkan pernah mengalami keterpurukan dan putus asa dalam keadaan ini. Namun ia mulai realistis dengan penyakitnya, dan tidak terlalu tinggi menargetkan apa yang diinginkannya. Patisipan 3 juga berusaha untuk menerima kondisinya:

"Mimpi apa saya punya penyakit gini, tapi ya gak ambil pusing, katanya apa yang kita rasakan sakit ini mengurangi dosa kita. Saya yakin kok gitu. [...].”(P3 B828).

Partisipan masih tidak percaya bagaimana ia bisa kena skizofrenia, namun ia belajar untuk menerimanya dan mengambil sikap positif. Ia lebih ingin memikirkan bahwa Tuhan akan menghapus dosanya sebagai imbalan dari sakit yang ia alami.

\section{PEMBAHASAN}

Penelitian ini menemukan dua tema utama, yaitu tekanan yang dialami akibat skizofrenia dengan sub tema mendapatkan tanggapan negatif; kurangnya perhatian dari orang terdekat; mudah merasa lelah, dan mengalami kesepian. Tema kedua yaitu strategi coping untuk mengatasi masalah yang terdiri atas dua sub-tema, penyelesaian berfokus pada masalah dan penyelesaian berfokus pada emosi. Strategi coping yang berfokus pada emosi terdiri meliputi mengalihkan tekanan ke aktivitas lain; mengabaikan tanggapan negatif; mengambil pandangan positif, mencari dukungan moral; dan menerima kondisi.

Sirait (2008) dalam penelitiannya menjelaskan bahwa penderita skizofrenia yang sudah sembuh dan kembali ke masyarakat tidaklah mudah untuk diterima di masyarakat. Skizofrenia dipandang tidak dapat disembuhkan, hal inilah yang kemudian menyebabkan penderita skizofrenia mendapat label negatif misalnya dengan julukan stress atau gendeng. Catherine van Zelst (2009 menjelaskan stigmatisasi menunjukkan sebuah interaksi negatif yang kronis dengan lingkungan yang harus dihadapi oleh pasien skizofrenia dalam kehidupan sehari-hari. Situasi semacam itu dapat berakibat mudahnya para pasien skizofrenia rawat jalan (remisi) mengalami stress.

Peningkatan stres meningkatkan kemungkinan kekambuhan (Davison, 2010:469). Stres yang berlebihan bahkan dapat menyebabkan kekambuhan lebih parah (Siswanto 2007). Individu yang menderita skizofrenia tampak sangat reaktif terhadap berbagai stressor yang kita hadapi dalam kehidupan sehari-hari. Stres yang dialami dapat memicu mood yang negatif maupun positif. Mood yang negatif menyebabkan penderita skizofrenia terbebani dengan kegiatan sehari-hari yang harus dilakukannya. Seperti yang dialami oleh Partisipan 2 dan partisipan 3 juga mudah stres karena masalah ringan yang dihadapinya. Partisipan 2 mudah stres dengan kegiatan rumah yang harus diselesaikan. Sedangkan, pada partisipan 3 mengalami kondisi di mana dirinya belum mempunyai seorang anak dalam pernikahannya disebabkan suaminya yang divonis mandul. Kudo dkk. (2002) menjelaskan bahwa pasien remisi yang sedang menjalani terapi pada fase remisi awal bahkan berkelanjutan, ia akan mudah lelah, mengalami kesepian, dan menginginkan seorang teman atau pasangan.

Keluarga atau orang terdekat dapat memberikan dampak penting pada penderita skiozfrenia yang masih menjalani pengobatan rawat jalan untuk membantu mereka dalam melakukan penyesuaian. Namun, terkadang keluarga mengabaikan salah satu anggotanya yang masih menjalani rawat jalan. Pada awal kekambuhan, biasanya keluarga akan menunjukkan kepedulian dan perhatiannya, 
semakin lama semua akan berubah. Kurangnya perhatian oleh orang terdekat dialami oleh partisipan 2 dan partisipan 3. Partisipan 2 merasa ayah dan adiknya di rumah tidak lagi memperhatikannya seperti menemaninya keluar, sedangkan partisipan 3 merasa suaminya tidak menunjukkan kepedulian terhadap kesedihan yang dialaminya.

Selain kurang mendapatkan perhatian dari orang terdekat. Kesepian juga merupakan tekanan yang dialami oleh partisipan 2 dan partisipan 3. Partisipan 2 merasa bosan karena semangat dirinya yang sekarang berbeda seperti yang dulu dan mulai kesepian sebab belum mempunyai seorang suami. Sedangkan, yang dialami oleh partisipan 3 dirinya bosan kesehariannya tidak mempunyai seorang teman dekat yang dapat saling berbagi cerita dan belum mempunyai seorang anak.

Tekanan-tekanan yang dialami oleh partisipan 2 dan partisipan 3 seperti yang sudah dijelaskan sebelumnya seperti kurangnya perhatian dari orang terdekat dan kesepian karena skizofrenia dapat dibahas dengan menggunakan asumsi hierarki kebutuhan Maslow. Kebutuhan untuk dimiliki dan dicintai oleh orang lain tidak dapat terwujud sepenuhnya oleh partisipan 2 dan partisipan 3 seperti kebutuhan untuk dekat dengan keluarga. Tidak terpenuhinya kebutuhan untuk dimiliki, dicintai dan sayangi menyebabkan rentannya kedua partisipan untuk mengalami kekambuhan.

Untuk mengatasi semua tekanan yang dialami ketiga partisipan melakukan upaya penyelesaian masalah dalam menghadapi tekanan-tekanan tersebut. Kar (2009) menjelaskan salah satu kunci dari pengobatan yaitu penalaran dan pemecahan terhadap masalah. Penyelesaian masalah atau strategi coping yang digunakan oleh ketiga partisipan ada dua, yaitu penyelesaian berfokus pada masalah dan penyelesaian berfokus pada emosi.

Penyelesaian berfokus pada masalah dilakukan oleh individu secara aktif untuk menghilangkan kondisi yang menimbulkan stres (Folkman \& Lazarus, 1984).
Penyelesaian yang berfokus pada masalah dilakukan oleh ketiga partisipan dengan cara mencari informasi dan bantuan secara langsung seperti bercerita kepada orang terdekat dan pada teman di komunitas, seperti yang yang dilakukan pada partisipan 2 dan partisipan 3 .

Usaha penyelesaian masalah secara langsung juga dipengaruhi oleh faktor lain, seperti kemandirian dan keterbukaan terhadap masalah. Hal tersebut dilakukan oleh partisipan 3. Terbiasa mandiri sejak kecil membantunya mampu menyelesaikan upayaupaya sendiri dalam menyelesaikan masalah dihadapai hingga saat ini. Hal tersebut juga diiringi dengan keterbukaan dirinya dalam menceritakan masalah kepada orang lain, menurutnya skizofrenia bukanlah aib.

Selain menggunakan strategi penyelesaian yang berfokus pada masalah, ketiga partispan juga menggunakan strategi penyelesaian berfokus pada emosi. Penyelesaian berfokus pada emosi ini bertujuan untuk mengontrol emosi terhadap situasi stres yang menekan. Untuk menghadapi halusinasi partisipan 1 dan dan partisipan 3 memilih mengalihkannya pada kegiatan lain. Partisipan 1 melakukan aktivitas seperti bermain gitar dan berkumpul bersama teman. Pada partisipan 3 mengalihkan halusinasi dengan cara melakukan aktivitas seperti keterampilan tangan, mengaji, mendengarkan dan menyanyikan sebuah lagu.

Hal ini serupa dengan pendapat Wykes, (dalam Farhall 2007), yang melaporkan bahwa mendengarkan musik yang menenangkan cocok untuk menurunkan halusinasi yang mulai ringan. Mendengarkan musik dapat membantu partisipan mengontrol emosi terhadap halusinasi yang didengarnya ketika suara halusinasi yang muncul mulai menjengkelkan. Kemudian efektivitas lainnya yaitu fokus terhadap pengurangan kecemasan dengan mengalihkan perhatian (Slade \& Ben, 1988 dalam Farhall 2007).

Usaha mengabaikan tekanan juga dilakukan oleh partisipan 1 dan partisipan 2 ketika mendapatkan tanggapan negatif dari orang lain. Selain mengabaikan tanggapan 
negatif dari orang lain, partisipan 1 dan partisipan 2 berusaha menahan dan mengekspresikan emosi. Partisipan 1 akan mengeskpresikan marahnya kepada diri sendiri seperti memaki diri sendiri. Sedangkan, partisipan 2 memilih menahan sakit hatinya dengan diam.

Mencari dukungan sosial berupa simpati dari orang lain dilakukan oleh ketiga partisipan agar mendapatkan ketenangan emosi. Hal tersebut dilakukan oleh ketiga partisipan dengan menceritakan masalahnya kepada orang terdekat. Mendapatkan informasi dari orang terdekat serta mendekatkan ketengan rohani membantu ketigan partisipan untuk mengubah pandangan tentang tekanan yang dialaminya dan memikirkan konsekuensinya bahwa keadaan bisa saja menjadi lebih buruk. upaya penyelesaian yang berfokus pada emosi ini seperti proses yang berkelanjutan dengan upaya apa selanjutnya yang akan dilakukan. Setelah upaya sebelumnya dilakukan, membuat ketiga partisipan mampu menerima kondisi dan mengambil makna positif atas tekanan yang dialaminya.

Efektifnya strategi yang digunakan bergantung dengan seberasa sulitnya tekanan yang dialaminya. Usaha penyelesaian yang berfokus pada masalah dilakukan oleh ketiga partisipan dengan tindakan secara langsung. Usaha yang telah dilakukan membuat mereka bertindak aktif dan mendapatkan manfaat positif secara langsung. Sedangkan, usaha penyelesaian berfokus pada emosi, dilakukan oleh ketiga partisipan, mungkin saja tekanan yang dialami dirasa sulit dan tidak dapat diubah dengan tindakan langsung yang akan memperoleh hasil begitu cepat. Selain keterlibatan diri sendiri dalam menyelesaikan tekanan yang dialami, peran dukungan sosial sangat berarti membantu ketiga partisipan dalam menyelesaikan masalahnya.

Friedman (dalam Fahanani, 2010:4) menjelaskan dampak stres tidak akan terlalu kuat apabila ada dukungan sosial, dukungan sosial dapat membantu individu untuk memperkokoh kesehatan mentalnya, karena dukungan sosial adalah strategi coping yang penting dalam keluarga saat berada dalam situasi stres. Kemudian, harga diri untuk bekerja yang dilakukan ketiga partisipan agar dihargai oleh orang lain juga menjadi faktor. Ketiga partisipan mencari aktivitas lain untuk mengalihkan diri dari tekanan yang dialaminya.

Hasil temuan ini selaras dengan hasil penelitian Dongen (1998; dalam Daryanto, 2008:81), yang mengatakan bahwa diantara individu yang mengalami penyakit mental berat, harga diri positif lebih bermakna tinggi didapat oleh individu yang bekerja dibandingkan yang tidak bekerja. Asquith (Daryanto, 2008:81) mengatakan anak perempuan lebih mengalami harga diri rendah pada anak laki-laki. Perempuan dewasa sudah mampu menjalani tahap perkembangan dalam hidupnya dengan matang, sehingga mereka mengembangkan harga dirinya arag dihargai oleh orang lain. Berdasarkan analisa peneltian ini secara kebetulan didimonasi oleh 2 partisipan perempuan, sehingga perbedaan jenis kelamin kurang bisa menggambarkan mana yang lebih cenderung memiliki harga diri tinggi. Dalam hal ini, ketiga partisipan memiliki harga diri yang sama yaitu untuk bekerja agar dihargai.

Berdasarkan strategi coping yang digunakan, ketiga partisipan lebih sering melakukan strategi penyelesaian terhadap emosi. Hal ini serupa dengan pendapat Storus dkk. (2005), (dalam Cross, 2010), yang mengatakan bawah pada fase eksaserbasi (penderita merasa sakit) skizofrenia serta rentan mengalami tingkat tekanan emosional yang tinggi dalam kehidupan mereka, penyelesaian berfokus pada emosi mungkin akan lebih sering digunakan. Fase eksasebasi skizofrenia adalah fase ketika ketiga partisipan merasa kurang baik. Peneliti mengasumsikan, walau sudah dinyatakan remisi, bukan berarti ketiga partisipan tidak mengalami fase ketika mereka merasa kurang baik. Seperti kecemasan, atau gangguan dari tekanan yang dialami akibat skizofrenia.

Coping yang digunakan membatu ketiga partisipan untuk menyelesaikan masalah. Efektivitas coping bergantung terhadap masalah dan cara yang digunakannya. Ketiga partisipan 
menunjukkan bahwa coping yang digunakan memberikan manfaat positif. Walau, tidak sepunuhnya membantu menyelesaikan masalah secera keseluruhan, coping memberikan manfaat pada ketiga partisipan untuk beradaptasi, dan mengutangi tekanan yang ada. Menyelesaikan tekanan yang ada dengan menggunakan strategi coping juga mendorong ketiga partisipan untuk terlepas dari dampak buruk tekanan yang dialami sehingga ketiga partisipan dapat menjalani kehidupannya dimasa mendatang. Keefektivan coping dan penerimaan positif memberikan kehidupan yang bermakna untuk ketiga partisipan. Rubyyana (2012:64) menjelaskan bahwa strategi coping yang adaptif akan meningkatkan kualitas hidup penderita skizofrenia. Coping adaptif dilakukan invidividu untuk mendapatkan hasil atau kontribusi yang positif dengan cara yang dilakukannya. Kualitas hidup untuk mencapai kesehatan fisik, terlepas dari efek negatif obat, hubungan sosial yang baik dan kemampuan untuk melakukan aktivitas kemandirian lainnya.

Upaya yang ketiga partisipan mungkin tidak mampu secara optimal dan seperti sebelum mengalami gangguan skizofrenia. Namun, ketiga partisipan berusaha sepunuhnya untuk lebih baik. Putri (2012:150) menyimpulkan bahwa meski dalam kondisi yang belum sembuh secara total dari gejala-gejala skiozfrenia, penderita apabila menginat tanggung jawab, penderita skizofrenia akan memiliki keinginan dengan membuat dirinya lebih bermakna dibandingkan dengan sebelumnya. Hal tersebut dimiliki oleh ketiga partisipan, mengingat tanggung jawab dengan proses kehidupan yang harus terus dijalani membuat mereka terus berusaha dengan mengubah pandangan tentang tekanan kemudian menerima keadaan ini dengan makna yang positif.

\section{SIMPULAN}

Penderita skizofrenia yang masih menjalani pengobatan rawat jalan dalam penelitian ini mengalami beberapa stressor. Usaha coping dapat dilakukan oleh mereka di gunakan untuk mengatasi stressor. Ada dua strategi coping yang dilakukan yaitu penyelesaian berfokus pada masalah dan emosi. Secara umum, upaya coping yang dilakukan membantu partisipan untuk aktif menyelesaikan seluruh stressor, walau ada beberapas stressor yang masih belum dapat terselesaikan. Penyelesaian berfokus pada masalah dilakukan dengnn cara aktif mencari informasi, perencanaan dan mencari dukungan secara langsung untuk segera menyelesaikan masalah. Partisipan dalam penelitian ini lebih sering menggunakan penyelesaian yang berfokus pada emosi. Ketika stressor yang dihadapi tidak dapat diselesaikan menggunakan penyelesaian berfokus pada masalah kemudian partisipan melakukan upaya dengan menggunakan penyelesaian berfokus pada emosi. Penyelesaian berfokus pada emosi sebagai upaya untuk mengatur emosi positif ketika stessor yang dialami tidak dapat terselesaikan secara langsung. Penyelesaian berfokus pada emosi dilakukan dengan cara mencoba mengalihkan stressor, mencari dukungan moral, mendekatkan diri kepada Tuhan, kemudian mengubah pandangan dala, hal positif dan menerima kondisi.

Coping merupakan proses kognitif, partisipan dalam penelitian ini telah melakukan upaya coping. Kemampuan coping partisipan menunjukkan rendahnya resiko kekambuhan karena partisipan dalam penelitian ini mampu mengatur dan mengendalikan diri dari stressor yang muncul dan menerima keadaan dengan makna positif

untuk menjalani kehidupan mendatang. Untuk Upaya ini efektif mengurangi beban pikiran dari stressor yang dihadapi dan mengurangi resiko kekambuhan. 


\section{Daftar Pustaka}

Badan Penelitian dan Pengembangan Kesehatan Departemen Kesehatan Republik Indonesia. (2008). Riset Kesehatan Dasar 2007. Jakarta: Departemen Kesehatan Republik Indonesia. Diakses dari

http://www.litbang.depkes.go.id/bl_risk esdas2007/ pada 12 Januari 2013.

Badan Pusat Statistik. (2010). Penduduk Indonesia Menurut Kota/Kabupaten dan kecamatan: Sensus Penduduk Tahun 2010. Jakarta: Badan Pusat Statistik. Diakses dari http://sp2010.bps.go.id/files/ebook/pop \%20indo_kab_kota_kec_rev20101224/i ndex.html. pada 12 Januari 2013.

Braun, V., \& Clarke, V. (2006). Using Thematic Analysis in Psychology. Qualitative Research in Psychology, 3, 77-101.

Cross, L. E., \& Rudnick, A. (2010). Coping with Comorbid Cancer and Schizophrenia: A Case Series Analysis. Diakses dari http://www.psychosiscoal.com/IJPR_15 I

Coping_with_Comorbid_Cancer_and_

MI_Cross.html. pada 01 Mei 2013

Daryanto. (2008). Hubungan karakteristik Klien, Keluarga dan Stigma dengan Dukungan Keluarga pada Klien Harga Diri Rendah [skripsi]. Jambi: Universitas Batanghari.

Departemen Kesehatan Republik Indonesia. (1993). Pedoman Penggolongan dan Diagnosis Gangguan Jiwa di Indonesia III (PPDGJ-III). Jakarta: Departemen Kesehatan Republik Indonesia

Drake, R. E., McHugo, G. J., Xie, H., Fox, M., Packard, J. \& Helmstetter, B. (2006). Ten-Year Recovey Outcomes for Clients With Co-Occurring Schizophrenia and Substance Ise Disorders. Schizophrenia Bulletin, 32(3), 464-473.

Drapeau, A., Marchand, A., \& BeaulieuPrévost, D. (2006). Epidemiology of Psychological Distress. In Luciano LAbate (Ed.). Mental Illnesses Understanding, Prediction and Control.(pp. 105-134). Diakses dari http://www.intechopen.com/books/ment al-illnesses-understanding-predictionand-control/epidemiology-ofpsychological-distress pada 30 Juni 2013.

Davison, G. C., Neale, J. M., \& Kring, A. M. (2006). Psikologi Abnormal. Edisi ke 9. Jakarta: PT. Raja Grafindo Persada.

Elliot, R., Fiscer, C. Y., \& Rennie, D. L. (1999). Evolving Guidelines for Publication of Qualitative Research Studies In Psychology and Related Fields. British Journal of Clinical Psychology 38, 215229.

Emzir . (2011). Metode Penelitian Kualitatif: Analisis Data. Jakarta: Rajawali Pers

Fahanani, G, F. (2010). Hubungan Pengetahuan Tentang Gangguan Jiwa dengan Dukungan Keluarga yang Mempunyai Anggota Skizofrenia di RSJD Surakarta. Surakarta: Universitas Muhamadiyah. [Skripsi]. [Online] Diakses dari etd.eprints.ums.ac.id/9479/. Pada tanggal 15 April 2013

Farhall J, Greenwood K. M, \& Jackson H. J. (2007). Coping with hallucinated voices in schizophrenia: a review of self-initiated strategies and therapeitic intervention. Clinical Psychology Review, 27 (4), 476-493.

Jetha, M. K., Goldberg, J. O. \& Schmidt. L. A. (2013). Temperament and its Relation to Social Functioning in Schizophrenia. International Journal of Social Psychiatry, 59 (3), 254-263.

Kar, N. (2009). Recovery From Schizophrenia: From Relentless Pessimism to Caution Optimism. Orissa Journal Psychiatry, 16, 6-12. Diakses dari : http://www.orissajp.com/pdf/09/2.pdf. pada 9 Maret 2012.

Kudo, J., Mori, H., \& Gomibuchi, T. (2002). Loneliness as expressed by schizophrenic patients in the early remission phase. Nagoya J. Med. Sci, 65, 115-126.

Kompas Online. (11 Oktober 2011). Gangguan Jiwa Meningkat. Diakses dari: http://health.kompas.com/read/2011/10 /11/03332452/Gangguan.Jiwa.Meningk at. pada 20 Februari 2012 
Nevid, J.S., Rathus, S.A., Greene, B. (2003). Psikologi Abnormal. Edisi 5. Jilid 2 (Terjemahan). Jakarta : Penerbit Erlangga.

Moleong, L. J. (2010). Metode Penelitian Kualitatif (Edisi Revisi). Bandung: PT. Remaja Rosdakarya

Poerwandari, K. E. (2001). Pendekatan Kualitatif Untuk Penelitian Perilaku Manusia. Jakarta: Lembaga Pengembangan Sarana Pengukuran dan Pendidikan Psikologi (LPSP3) Fakultas Psikologi Universitas Indonesia

Sirait, A. (2008). Pengaruh Koping Keluarga terhadap Relaps pada Skizofrenia Remisi Sempurna di Rumah Sakit Jiwa Daerah Propinsi Sumatera Utara. [Thesis] : Universitas Sumatera Utara.

Siswanto, (2007). Kesehatan Mental: Konsep, Cakupan dan Perkembangannya. Yogyakarta: ANDI

Smet, B. (1994). Psikologi kesehatan. Jakarta: PT. Gramedia Widiasarana Indonesia

Yin, K. R. (2000). Studi Kasus (Desain dan Metode). Jakarta: Rajawali Pers

van Zelst, C. (2009). Stigmatization as an Environmental Risk in Schizophrenia: A User Perspective. Schizophrenia Bulletin, 35(2), 293-296. Diakses dari: http://www.ncbi.nlm.nih.gov/pmc/articl es/PMC2659317/. pada 9 Maret 2012.

Yanos, P. T., Roe, D., Markus, K.\& Lysaker, P. H. (2008). Pathways Between Internalized Stigma and Outcomes Related to Recovery in Schizophrenia Spectrum Disorders. Psychiatric Services, 59(12), 1437-1442. Diakses dari:

http://journals.psychiatryonline.org/dat a/Journals/PSS/3865/08ps1437.pdf pada tanggal 9 Maret 2012.

Kartono, K (1990) Psikologi Umum, Bandung : Penerbit Mandar Maju
Kompasiana, 30 Mei (2010). Mengontrol Halusinasi. Diakses dari : http://kesehatan.kompasiana.com/kejiw aan/2010/05/30/mengontrolhalusinasi-153757.html pada 20 Mei 2013.

Komunitas Peduli Skizofrenia Indonesia diakses tanggal 10 Mei 2012 https://www.facebook.com/groups/skiz ofrenia/

Lazarus, R.S. (1979). Patterns of adjustment. Kogakusha: McGraw-Hill.

Mahdy, Hajid Al. (22 April 2013). A Beautiful Mind. (Artikel Online) http://ceritahajid.wordpress.com/2013/ 04/22/a-beautiful-mind/ diakes pada tanggal 20 Mei 2013.

Marpaung, V. R. B. (2010). Hubungan Ketidakpatuhan Pengobatan Dan Stigma Pada Keluarga Dengan Perawatan Kembali Pasien Skizofrenia Di RSJ Daerah Provinsi Sumatera Utara. Skripsi.Tidak diterbitkan. Medan: Fakultas Ilmu Kesehatan Masyarakat. Universitas Sumatra Utara.

Pramadi, A. \& Lasmono, H.K (2000). Coping stress pada etnis Bali, Jawa, dan Sunda. Anima: Indonesian Psychological Journal. 2 (4). 326-340.

Psikolove, (2012). Dinamika Psikologis Pasien Skizofrenia. (Artikel Online) http://shellasitiacil.blogspot.com/2012/ 05/dinamika-psikologis-pasien.html. diakses pada tanggal 7 Oktober 2012

Putri, K.P., Ambarini, K.T,. (2012). Makna Hidup Penderita Skizofrenia Pasca Rawat Inap. Jurnal Psikologi Klinis dan Kesehatan Mental, 1 (2).

Rubbyana, Urifah. (2012). Hubungan antara Strategi Koping dengan Kualitas Hidup pada Penderita Skizofrenia Remisi Simptom. Jurnal Psikologi Klinis dan Kesehatan Mental, 1 (2). 